\title{
Research into the influence of contrasting trophic conditions of vernalization on the allelic state of Vrn genes and development rates of Triticum aestivum $\mathrm{L}$.
}

\author{
Olga O. Avksentiieva ${ }^{1,2}$, \\ Victoriia V. Shulik ${ }^{1}$, \\ Nataliya Yu. Taran ${ }^{2}$ \\ ${ }^{1}$ V. N. Karazin Kharkiv \\ National University, \\ 4 Svobody Sq., \\ Kharkiv 61022, Ukraine \\ ${ }^{2}$ Taras Shevchenko \\ National University of Kyiv, \\ 64/13 Volodymyrska Street, \\ Kyiv 01601, Ukraine
}

The influence of contrasting trophic conditions of vernalization on the allelic state of the Vrn genes and development rates of two winter wheat varieties, Mironovskaya 808 and Olvia, was investigated. Vernalization was carried out during 45 days at the temperature $4 \pm 1^{\circ} \mathrm{C}$ under different conditions of trophic support. Whole seeds with endosperm and isolated buds, with added water and $3 \%$ solution of sucrose, were vernalized. The allelic state of the Vrn genes was identified by PCR using allele-specific primers on the sprouts at different phases of vernalization - 15, 30 , and 45 days. Phenological observations were carried out by determining of the transition to the generative development of wheat plants, cultivated from the vernalized sprouts. According to the results obtained, it was established that the recessive state of the genes Vrn-A1, Vrn-B1 and Vrn-D1 was unchanged in all variants of the two winter wheat varieties on the 15th and 30th days of vernalization. After 45 days of vernalization, the recessive and dominant alleles in sprouts, vernalized under normal trophic conditions and with added $3 \%$ solution of sucrose, were detected at the $V r n-B 1$. All variants of wheat plants grown from vernalized sprouts under contrasting trophic conditions were transferred to the generative phase, but at different times. It could indicate an epigenetic regulation vernalization process. It was established that different trophic conditions during vernalization affected the changes of the allelic state of the Vrn-B1 gene and determined the transition to the generative development of winter wheat.

Keywords: Triticum aestivum L., vernalization, Vrn genes, trophic support, PCR, development rates, allelic state of Vrn genes

\section{INTRODUCTION}

Transition from the vegetative to the generative phase of development is one of the most impor-

\footnotetext{
* Corresponding author. Email: viktoria.shulik@karazin.ua
}

tant stages of plant ontogenesis. In cereals, in particular soft winter wheat Triticum aestivum L., this phenomenon is caused by the effect of low positive temperatures - vernalization (Henderson et al., 2003; Dennis, Peacock, 2009). It is known that genetic control of the vernalization requirement 
(Stelmach et al., 2000) and growth habit (spring or winter) of Triticum aestivum L. are determined by the Vrn (vernalization) genes system, consisting of 3-5 orthologous loci (Cocram et al., 2007). The three main genes - Vrn-A1,Vrn-B1, and $V r n-D 1$ - are localized in chromosomes 5A, 5B, and $5 \mathrm{D}$, respectively. The presence of three main recessive Vrn alleles in the homozygous state determines the habit of winter growth. In this case, the presence of one dominant $V r n-A 1$ gene causes plant insensitivity to vernalization, and dominant $V r n-B 1$ and $V r n-D 1$ genes only partially reduce the vernalization requirement (Distelfeld et al., 2009). The Vrn genes are actively investigated at the level of molecular genetics and have been cloned. In recent years, several allelic variants of wheat have been described (Fu, 2005; Chu, 2011). The Vrn-A1 encodes a MADS-box transcription factor (Trevaskis, 2010), Vrn-B1 locus consists of two tandem duplicated ZCCT genes suppressing flowering, and $V r n-D 1$ encodes a RAF kinase inhibitor-like protein (Distelfeld et al., 2009). The physiological process of vernalization of winter wheat is regulated by endogenous genetic control and depends on exogenous factors - the conditions that can affect the epigenetic regulation expression of Vrn genes (Song, 2102; Sherban, Salina, 2013; Kim, Sung, 2014). A complex of different external and internal factors is important for effectiveness of vernalization. Among them, the most important are trophic factors (Dennis, 2009). The requirement of metabolites during vernalization at the sprout phase is supported by a reserve of plastic substances of endosperm. Mainly, carbohydrates play a role as signal molecules - the universal regulators of gene expression determining the processes of plant growth, development, and floral morphogenesis (Koch, 2004; Everland, Jackson, 2011). The influence of sugars on seed germination has been widely investigated (Aoki et al., 2006). It has been established that sugars are capable of suppressing the mobilization of nutrients, growth, and elongation of the sprout above-ground part (Rolland, Moore, Sheen, 2002). The exogenous sucrose, probably, compensates the activity of regulators of development of shoot and root meristems, and promotes cell division by regulating of the $C y c D$ genes expression (Riou-Khamlichi et al., 2000). The main aim of the work was to investigate the influence of contrasting trophic conditions of vernalization on the allelic state of Vrn genes and rates of development of two winter wheat varieties, Mironovskaya 808 and Olvia.

\section{MATERIALS AND METHODS}

Plant material. Seeds of two soft winter wheat varieties - Mironovskaya 808 and Olvia - were used. To carry out PCR analysis of the allelic state of Vrn genes, six near isogenic lines (NILs) and the original variety Paha with known alleles/genes, with index numbers at the National Society of Genetic Counselors (NSGC), were used as control variants.

Vegetative experiments. Vegetative experiments of the study were carried out at the Department of Plant and Microorganism Physiology and Biochemistry of V. N. Karazin Kharkiv National University. Winter wheat grains were sterilized by $15 \%$ solution of sodium hypochlorite and germinated in the dark at a temperature of $22 \pm 2^{\circ} \mathrm{C}$ for two days. The buds were isolated in sterile conditions in a laminar box. Vernalization was carried out during 45 days at a temperature of $4 \pm 1^{\circ} \mathrm{C}$ under contrasting conditions of trophic support. Integral seeds with endosperm (natural trophic vernalization support) were vernalized as the control variant, and isolated buds with added water (without trophic support) and 3\% sucrose solution (artificial trophic support) as experimental variants.

PCR analysis. To carry out the molecular genetic analyses, the sprouts were used at different stages of vernalization - 15, 30, and 45 days. DNA was isolated using a set of reagents "Diatom Prep 100" according to the manufacturer's method. The allele specific primers (Mass Wheat, http://maswheat.ucdavis.edu) were used to study the allelic state of the Vrn$A 1, V r n-B 1$ and Vrn-D1 genes (Table 1).

PCR analysis was carried out with a multichannel thermocycler "Tercycle" (DNA technology, Russia) according to standard conditions of amplification of the allele-specific primers (Table 2). 
Table 1. Primers for identification of different alleles of genes in hexaploid wheat (Mass Wheat)

\begin{tabular}{|c|c|c|c|c|}
\hline Gene & Allele & Primers & Sequence & Product size (bp) \\
\hline \multirow{8}{*}{$V r n-A 1$} & Vrn-A1a & \multirow{4}{*}{$\begin{array}{l}\text { VRN AF VRN- } \\
\text { INT1R }\end{array}$} & \multirow{4}{*}{$\begin{array}{l}\text { GAAAGGAAAAATTCTGCTCG } \\
\text { GCAGGAAATCGAAATCGAAG }\end{array}$} & $965+876$ \\
\hline & $V r n-A 1 b$ & & & 714 \\
\hline & $V r n-A 1 c$ & & & 734 \\
\hline & $v r n-A 1$ & & & 734 \\
\hline & $V r n-A 1 a$ & \multirow{4}{*}{$\begin{array}{l}\text { VRN AF } \\
\text { VRN1R }\end{array}$} & \multirow{4}{*}{$\begin{array}{l}\text { GAA AGGAAAAATTCTGCTCG } \\
\text { TGCACCTTCCCCCGCCCCAT }\end{array}$} & $750+650$ \\
\hline & $V r n-A 1 b$ & & & 480 \\
\hline & $v r n-A 1$ & & & 500 \\
\hline & $V r n-A 1 c$ & & & 500 \\
\hline \multirow{2}{*}{$V r n-A 1$} & \multirow{2}{*}{$V r n-A 1 c$} & Intr1/A/F2 & AGCCTCCACGGTTTGAAAGTAA & \multirow{2}{*}{1170} \\
\hline & & Intr1/A/R3 & AAGTAAGACAACACGAATGTGAGA & \\
\hline \multirow{2}{*}{$V r n-A 1$} & \multirow{2}{*}{$v r n-A 1$} & Intr1/C/F & GCACTCCTAACCCACTAACC TCATC- & \multirow{2}{*}{1068} \\
\hline & & Intr $1 / \mathrm{AB} / \mathrm{R}$ & CATCATCAAGGCAAA & \\
\hline \multirow{2}{*}{$V r n-B 1$} & \multirow{2}{*}{$V r n-B 1$} & $\operatorname{Intr} 1 / \mathrm{B} / \mathrm{F}$ & CAAGTGGAACGGTTAGGACA & \multirow{2}{*}{709} \\
\hline & & Intr/B/R3 & CTCATGCCAAAAATTGAAGATGA & \\
\hline \multirow{2}{*}{$V r n-B 1$} & \multirow{2}{*}{$v r n-B 1$} & Intr1/B/F & CAAGTGGAACGGTTAGGACA & \multirow{2}{*}{1149} \\
\hline & & Intr/B/R4 & CAAATGAAAAGGAATGAGAGCA & \\
\hline \multirow{2}{*}{ Vrn-D1 } & \multirow{2}{*}{$V r n-D 1$} & $\operatorname{Intr} 1 / \mathrm{D} / \mathrm{F}$ & GTTGTCTGCCTCATCAAATCC GGT- & \multirow{2}{*}{1671} \\
\hline & & Intr1/D/R3 & CACTGGTGGTCTGTGC & \\
\hline \multirow{2}{*}{ Vrn-D1 } & \multirow{2}{*}{$v r n-D 1$} & Intr1/D/F & GTTGTCTGCCTCATCAAATCCAAAT- & \multirow{2}{*}{997} \\
\hline & & Intr1/D/R4 & GAAAAGGAACGAGAGCG & \\
\hline
\end{tabular}

Table 2. PCR conditions for allele-specific primers

\begin{tabular}{|c|c|c|c|c|c|c|}
\hline \multirow[b]{2}{*}{ Primers } & \multicolumn{6}{|c|}{ PCR conditions } \\
\hline & $\begin{array}{c}\text { Initial de- } \\
\text { naturation } \\
\mathbf{t}^{\circ}(\mathrm{min})\end{array}$ & $\begin{array}{l}\text { Number } \\
\text { of cycles }\end{array}$ & $\begin{array}{l}\text { Denatura- } \\
\text { tion } t^{\circ}(\mathrm{sec})\end{array}$ & $\begin{array}{c}\text { Annealing } \\
\mathbf{t}^{\circ}(\mathrm{sec})\end{array}$ & $\begin{array}{c}\text { Extension } \\
t^{\circ}(c)\end{array}$ & $\begin{array}{l}\text { Final exten- } \\
\operatorname{sion} t^{\circ}(\min )\end{array}$ \\
\hline $\begin{array}{l}\text { VRN AF // VRN- } \\
\text { INT1R }\end{array}$ & $94(10)$ & 38 & $94(45)$ & $55(45)$ & $72(60)$ & $72(5)$ \\
\hline VRN AF // VRN1R & $94(7)$ & 40 & $95(30)$ & $60(30)$ & $72(60)$ & $72(10)$ \\
\hline $\begin{array}{c}\text { Intr1/C/F // Intr1/ } \\
\mathrm{AB} / \mathrm{R} \\
\end{array}$ & $94(7)$ & 38 & $94(30)$ & $57(30)$ & $72(45)$ & $72(7)$ \\
\hline $\begin{array}{c}\text { Intr1/A/ } \\
\text { F2 // Intr1/A/R3 }\end{array}$ & $94(7)$ & 38 & $94(30)$ & $60(30)$ & $72(45)$ & $72(7)$ \\
\hline $\begin{array}{c}\text { Intr1/B/F // Intr/B/ } \\
\text { R3 // Intr/B/R4 }\end{array}$ & $94(10)$ & $\begin{array}{c}44 \text { (Touch- } \\
\text { down) }\end{array}$ & $94(45)$ & $58-63(45)$ & $72(69)$ & $72(10)$ \\
\hline $\begin{array}{c}\text { Intr1/D/F // Intr/D/ } \\
\text { R3 // Intr/D/R4 }\end{array}$ & $94(10)$ & $\begin{array}{l}44 \text { (Touch- } \\
\text { down) }\end{array}$ & $94(45)$ & $63-65(45)$ & $72(90)$ & $72(10)$ \\
\hline
\end{tabular}

The amplification products were observed by running on $1.5 \%$ agarose gel adding ethidium bromide $(10 \mathrm{mg} / \mathrm{ml})$ for $90-120$ minutes. The spectra of DNA fragments were estimated by using a $100 \mathrm{bp}$ molecular size ladder.
Phenological observations (phenotyping). After vernalization, phenological observations of the rate of development of winter wheat plants were carried out under conditions of vegetative experiment at the factorostatic chamber 
of the Department of Plant and Microorganism Physiology and Biochemistry of V. N. Karazin Kharkiv National University. The vernalized 45day sprouts (15 sprouts each) were planted in vegetation vessels and cultivated in the soil culture under regulated conditions: a temperature regime of $22 / 18^{\circ} \mathrm{C}$ (day/night), $15 \mathrm{kl}$ illumination, 16-hour photoperiod, $70 \%$ air humidity. The duration of the heading and earing period of all variants was determined by transition of more than $50 \%$ plants to a certain phenological phase of development.

Statistical analysis. Two biological series of experiments were carried out. Statistical analysis was conducted by using the OpenOffice software and Statistica 5.0. Results of the PCR analysis were evaluated by using TotalLab (TL120, v.2009).

\section{RESULTS}

According to the results obtained, the presence of all three Vrn-A1, Vrn-B1, Vrn-D1 genes in the recessive state was identified in 15-day sprouts vernalized under contrasting trophic support conditions (Fig. 1). The alleles of the $V r n-A 1$ gene were analyzed by using VRN AF and VRN-INT1R primers. An expected size of an amplified fragment of the most common dominant Vrn-Ala allele was 965 and $876 \mathrm{bp}$ and recessive $v r n-A 1$ allele was $734 \mathrm{bp}$ (Table 1). Among the variants, the recessive $v r n-A 1$ allele was found in all variants of both varieties Mironovskaya 808 and Olvia (Fig. 1a). The analysis of $V r n-B 1$ gene, using
Intr $1 / \mathrm{B} / \mathrm{F}$ and $\operatorname{Intr} / \mathrm{B} / \mathrm{R} 4$ primers, showed only recessive $v r n-B 1$ alleles with size of amplified fragment 1149 bp in all variants (Fig. 1b). Furthermore, the presence of only recessive $v r n-A 1$ allele (997 bp), using the Intr1/D/F and Intr1/D/ $\mathrm{R} 4$ primers, was shown in all variants of both varieties (Fig. 1c).

The changes in the allelic state of Vrn - Vrn$A 1, V r n-B 1, V r n-D 1$ genes were not found by performing molecular genetic analysis in the vernalized 30-day sprouts under different trophic support conditions (Fig. 2).

The expected size of the amplified fragments of the recessive $v r n-A 1$ allele were $734 \mathrm{bp}$ in all variants, using primers VRN AF // VRN-INT1R (Fig. 2a). The recessive $v r n-A 1$ (1149 bp) and $v r n$ D1 (997 bp) alleles were detected by Touchdown PCR using two primer pairs: Intr $1 / B / F$ with Int/B/R3 or Intr/B/R4 (Fig. 2b); Intr1/D/F with Intr1/D/R3 or Intr/D/R4, respectively (Fig. 2c).

The following results were obtained to study the allelic state of Vrn-A1, Vrn-B1, Vrn$D 1$ genes in vernalized sprouts during 45 days (Fig. 3). The alleles of Vrn-A1 gene and Vrn$D 1$ in all variants were represented only by recessive vrn-A1 (734 bp) and vrn-D1 (997 bp) (Fig. 3a, c). However, changes of allelic state of $V r n-B 1$ gene were observed. After 45 days of low positive temperature exposure, the recessive allele of $v r n-B 1$ (1149 bp) as well as the dominant Vrn-B1 (709 bp) (Fig. 3b) were found in vernalized sprouts under natural trophic conditions - the integral seeds with endosperm and

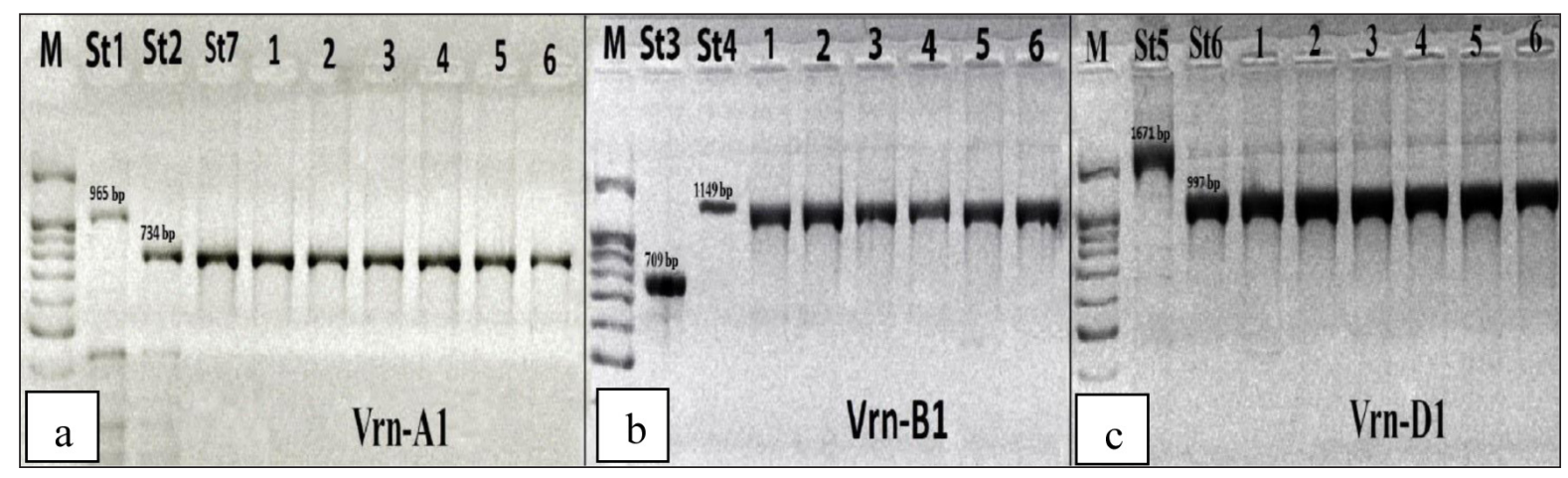

Fig. 1. Allelic state of the genes Vrn-A1 (a), Vrn-B1 (b) and Vrn-D1 (c) in 15-day vernalized wheat sprouts: Mironovskaya 808 ( 1 - integral seeds with endosperm, 2 - isolated buds + water, 3 - isolated buds + 3\% sucrose); Olvia (4 - integral seeds with endosperm, 5 - isolated buds + water, 6 - isolated buds $+3 \%$ sucrose) 


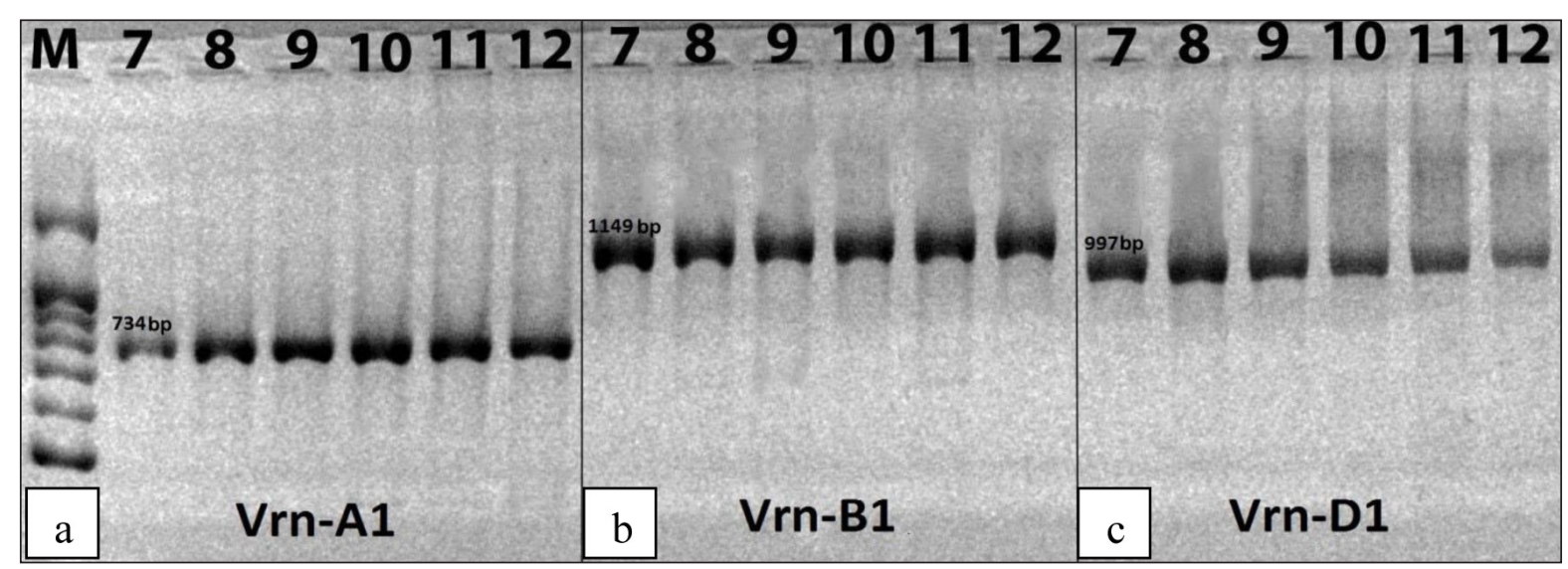

Fig. 2. Allelic state of the genes Vrn-A1 (a), Vrn-B1 (b) and Vrn-D1 (c) in 30-day vernalized wheat sprouts: Mironovskaya 808 ( 7 - integral seeds with endosperm, 8 - isolated buds + water, 9 - isolated buds $+3 \%$ susrose); Olvia (10 - integral seeds with endosperm, 11 - isolated buds + water, 12 - isolated buds $+3 \%$ sucrose)

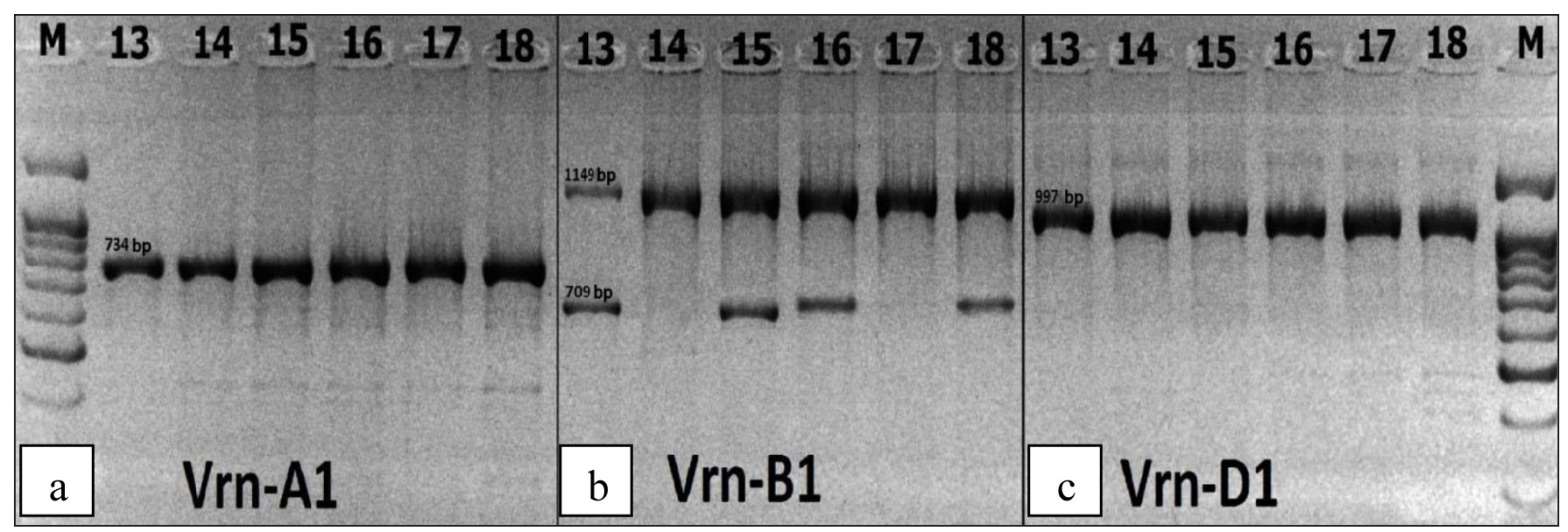

Fig. 3. Allelic state of the genes Vrn-A1 (a), Vrn-B1 (b), and Vrn-D1 (c) in 45-day vernalized wheat sprouts: Mironovskaya 808 (13 - integral seeds with endosperm, 14 - isolated buds + water, 15 - isolated buds + 3\% sucrose); Olvia (16 - integral seeds with endosperm, 17 - isolated buds + water, 18 - isolated buds $+3 \%$ sucrose)

variant with artificial trophic support - isolated buds $+3 \%$ sucrose solution.

$V r n-A 1$ gene is known to be the main gene determining the requirement or insensitivity of vernalization (Trevaskis, 2010; Stepanenko et al., 2012). A significant number of primers were used to study its allelic state (Table 1). The use of VRN-AF and VRN-INT1R primers made it possible to detect differences in the $v r n$ - $A 1$ allele from $V r n-A 1 a$ and $V r n-A 1 b$ alleles, but did not detect differences between $v r n-A 1$ and Vrn-A1, since the amplified fragment 734 bp can coincide with both $v r n-A 1$ and $V r n-A 1 c$ (Table 1$)$.

At the next stage of research, we used primers Intr $1 / \mathrm{C} / \mathrm{F}$ and $\operatorname{Intr} 1 / \mathrm{AB} / \mathrm{R}$ (Table 1 ). In spite of the duration of the vernalization period $-15,30$, and 45 days, the recessive $v r n-A 1$ allele (1068 bp) was identified in all variants of both winter wheat varieties (Fig. 4).

Thus, after 45 days of vernalization, the changes in the allelic state of $V r n-B 1$ gene were found under trophic factor effect. It should be noted that Vrn-B1 is the main repressor of flowering in the vernalization genetic system. The mutations remove the dependence of transition to generative phase on the conversion of genes from recessive to dominant state (Fu, 2005; Chu, 2011).

Based on the data obtained, it might be assumed that changes in the allelic state of Vrn-B1 gene depend on the duration and trophic support 


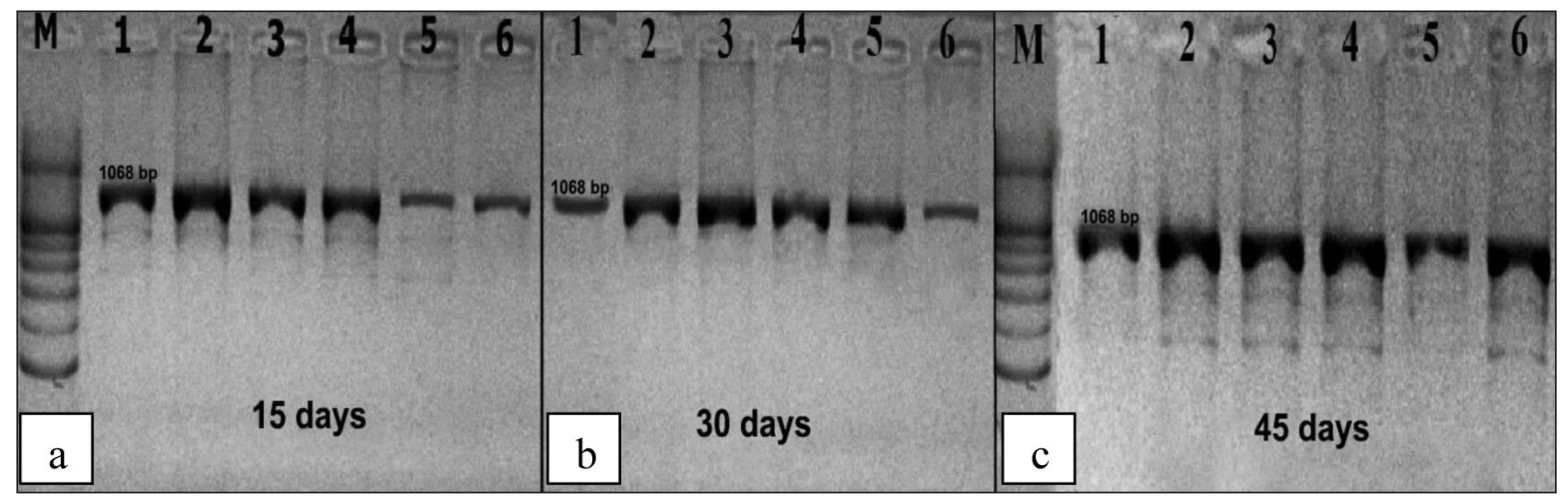

Fig. 4. Identification of $V r n-A 1 c$ and $v r n-A 1$ alleles with $\operatorname{Intr} 1 / \mathrm{C} / \mathrm{F}$ and $\operatorname{Intr} 1 / \mathrm{AB} / \mathrm{R}$ primers in vernalized sprouts under contrasting conditions of trophic support: Mironovskaya 808 (1 - integral seeds with endosperm, 2 - isolated buds + water, 3 - isolated water $+3 \%$ sucrose); Olvia ( 4 - integral seeds with endosperm, 5 - buds + water, 6 - isolated buds $+3 \%$ sucrose)

of vernalization. In our experiments, this factor was the presence of endosperm nutrients and 3\% sucrose solution.

Our previous studies showed that the rate of soft wheat development was determined by interaction of Vrn genes, which associated with the allelic state of vernalization genes (Avksentieva et al., 2015).

In further experiments, we investigated the duration of the heading and earing period of plants grown from vernalized sprouts during 45 days under contrasting trophic support conditions. It was shown that plants of both winter wheat varieties, Mironovskaya 808 and Olvia, transferred to earing during the vegetative pe- riod after 45-day vernalization (Table 3). We established that plants of Mironovskaya 808 had a longer vegetative period (75-81 days) compared with Olvia (62-68 days).

It should be noted that the survival rate of vernalized sprouts, as well as the number of plants transferred to earing differed significantly in the control and experiment variants (Table 3). The control plants of both varieties showed $100 \%$ survival rate and all plants transferred to earing during the experiment. The sprouts of two varieties, Mironovkaya 808 and Olvia, vernalized without trophic support (isolated buds + water), showed minimum survival rates $-67 \%$ and $63 \%$, respectively.

Table 3. Influence of the conditions of trophic support of sprout vernalization on the survival rate and duration of heading and earing period of two winter wheat varieties under conditions of vegetative experiment

\begin{tabular}{cccc}
\hline Vernalized variant & Survival rate, \% & Earing plants, \% & $\begin{array}{c}\text { Heading and earing } \\
\text { period, days }\end{array}$ \\
\hline & Variety Mironovskaya 808 \\
\hline Integral seeds with endosperm & $100 \pm 2$ & $100 \pm 1$ & $78 \pm 3$ \\
\hline Isolated buds + water & $13 \pm 1$ & $67 \pm 2$ & $100 \pm 6$ \\
\hline isolated buds + 3\% sucrose & $80 \pm 2$ & $83 \pm 2$ & $86 \pm 4$ \\
\hline Integral seeds with endosperm & $100 \pm 1$ & $65 \pm 3$ \\
\hline Isolated buds + water & $11 \pm 1$ & $100 \pm 1$ & $86 \pm 4$ \\
\hline Isolated buds + 3\% sucrose & $73 \pm 2$ & $63 \pm 2$ & $72 \pm 3$ \\
\hline
\end{tabular}


The plants of the investigated variants, vernalized under contrasting conditions of trophic support, transferred to earing, but at different times (Table 3). It could indicate that the genetic and epigenetic control of expression of vernalization genes was affected by low positive temperatures. The trophic support conditions of vernalization affected the rate of development and indicated the role of tropic support in the regulation of the process. The plants grown from isolated embryos and vernalized with water showed maximum delay of transition to the generative phase of development (earing) and duration of the vegetative period was maximum - 2122 days longer than that of the control variants (Table 3). The development rates of the variants vernalized with $3 \%$ sucrose solution were slower than the rate of the controls. The plants transferred to earing 7-8 days later. Thus, a reserve of the plastic substances of endosperm is necessary for normal development of wheat at the bud stage during vernalization, although sucrose could support the process.

\section{DISCUSSION}

It is known that Vrn genes are expressed during vernalization of winter wheat and barley, which determines the ability of plants to transfer to the generative phase of development (Chu et al., 2011; Fu et al., 2009; Trevaskis, 2010; Distelfeld et al., 2009). Furthermore, vernalization causes allelic changes in the Vrn-A1 gene through the occurrence of deletions or insertions either in the promoter or first intron, and in Vrn$B 1$ through the occurrence of the retrotransposon insert in the 5'UTR region (Chu et al., 2011). Genetic and molecular analysis identified the allelic variation of $V r n-B 1$ gene in tetraploid wheat, which was associated with a partially dominant effect (Distelfeld et al., 2009). It was established that winter or spring type of development of diploid wheat and barley was determined by allelic variation in the Vrn-A1 and Vrn-B1 genes, and in polyploid wheat species by allelic variation of Vrn-A1 (Fu et al., 2009). In our research, the variability of the allelic state of $V r n-B 1$ gene was also shown in the cultivation of primary and transplant callus culture of soft hexaploid wheat (Avksentyeva, Shulik, 2016).

Thus, the results obtained showed that a significant allelic variability of $V r n$ genes regulated growth habit, spring or winter. However, the possible association of allelic variability of $V r n$ genes with vernalization conditions, in particular, with trophic support of the process, was not investigated.

One of the main trophic factors that determine growth habit is carbohydrates. It has been shown that carbohydrates implement not only energy and plastic functions, but also signal molecules controlling the gene expression and coordinating multiple hormonal and stress signals (Rolland et al., 2002; Koch, 2004; Eveland, Jackson, 2012). Thereunder, we assumed that variations in $\mathrm{Vrn}$ genes could be revealed depending on trophic support. To test this assumption, we modeled different levels of trophic support by changing the endosperm to $3 \%$ solution of sucrose, the main transport sugar of plants.

According to the results obtained, it was established that $v r n-A 1, v r n-B 1$ and $v r n-D 1$ alleles were in the recessive state during 15 and 30 days of vernalization of sprouts with endosperm, isolated buds with added 3\% sucrose solution, and isolated buds with added water. After 45 days of vernalization, the changes of the allelic state of $V r n-B 1$ gene were identified in the variants with endosperm and 3\% sucrose. It could confirm the dependence of the allelic variability of $\mathrm{Vrn}-\mathrm{B1}$ gene on the trophic support of vernalization. In our experiments, all plants grown from vernalized sprouts under different trophic support conditions transferred to the generative phase. Therefore, the leading factor of the Vrn genes expression was temperature. At the same time, the plants of variants with endosperm and isolated buds with added 3\% sucrose transferred to earing earlier than isolated buds with added water. The important role of the trophic factor in regulating plant development rates was established.

\section{CONCLUSIONS}

The dependence of contrasting conditions of trophic support on the duration of vernalization 
process of two winter wheat varieties was demonstrated: the changes in the $V r n-B 1$ gene were detected only after 45 days of vernalization, but not after 15 and 30 days. It was established that the duration of the period before earing of wheat plants depended on the level of trophic support during the vernalization process.

According to the data obtained, in future studies the model used in the experiments can allow establishing the role of the trophic factor, in particular carbohydrates, in the mechanisms of Vrn genes expression, which promote an improvement of existing concepts of physiological and genetic mechanism of regulation of development rates in winter cereals.

\section{ACKNOWLEDGEMENTS}

The authors are grateful to the "AGROGEN" LLC in Kharkiv for assistance in acquiring allele-specific primers of Vrn genes, the Vrn genes NILs set, and variety Paha for carrying out molecular genetic research.

The authors thank Doctor of Biological Sciences, Professor Vasily V. Zhmurko for discussing the results.

The work was carried out within the research topic "Research of physiological, biochemical and molecular biological mechanisms of genetic control of development and production process of agricultural crops", state registration number No. 0112 U000101.

Received 27 May 2017 Accepted 20 December 2017

\section{References}

1. Aoki N, Scofield GN, Wang XD, Offler CE, Patrick JW, Furbank RT. Pathway of sugar transport in germinating wheat seeds. Plant Physiol 2006; 141(4): 1255-63.

2. Avksentyeva OA, Shulik VV, Zhmurko VV. Genes VRN allelic variants and paces of development in soft wheat isogenic lines. Factors of experimental evolution of organisms 2015; 17: Proceedings of the 10th Interna- tional Scientific Conference Chernovtsy, Kyiv: Vavilov Society of Geneticists and Breeders of Ukraine; 2015. p. 17-22. Russian.

3. Avksentyeva OA, Shulik VV. Allelic state and VRN genes effects of soft wheat in system in vivo and in vitro. Visnyk of Dnipropetrovsk University. Biology, ecology 2016; 24(1): 222-9. Ukrainian.

4. Chu CG, Tan CT, Yu GT, Zhong S, Xu SS, Yan L. A novel retrotransposon inserted in the dominant $V r n-b 1$ allele confers spring growth habit in tetraploid wheat (Triticum turgidum L.). G3(Bethesda) 2011; 1(7): 637-45.

5. Cocram J, Jones H, Leigh FJ, O'Sullivan D, Powell W, Laurie DA, Greenland AJ. Control of flowering time in temperate cereals: genes, domestication and sustainable productivity. J Exp Bot. 2007; 58(6): 1231-44.

6. Dennis ES, Peacock WJ. Vernalization in cereals. J Biol. 2009; 8(6): 57.

7. Distelfeld A, Li C, Dubcovsky J. Regulation of flowering in temperate cereals. Curr Opin Plant Biol. 2009; 12(2): 178-84.

8. Distelfeld A, Tranquilli G, Li C, Yan L, Dubcovsky J. Genetic and molecular characterization of the Vrn2 loci in tetraploid wheat. Plant Physiol. 2009; 149(1): 245-57.

9. Eveland AL, Jackson DP. Sugars, signalling, and plant development. J Exp Bot. 2012; 63(9): 3367-77.

10. Fu D, Szucs P, Yan L, Helguera M, Skinner JS, von Zitzewitz J, Hayes PM, Dubcovsky J. Large deletions within the first intron in Vrn-1 are associated with spring growth habit in barley and wheat. Mol Genet Genomics. 2005; 273(1): 54-65.

11. Henderson IR, Shindo C, Dean C. The need for winter in the switch to flowering. Annu Rev Genet. 2003; 37: 371-92.

12. Kim DH, Sung S. Genetic and epigenetic mechanism underlying vernalization. Arabidopsis Book. 2014: 1-15.

13. Koch K. Sucrose metabolism: regulatory mechanisms and pivotal roles in sugar sensing 
and plant development. Curr Opin Plant Biol. 2004; 7(3): 235-46.

14. Riou-Khamlichi C, Menges M, Healy J, Murray JA. Sugar control of the plant cell cycle: differential regulation of Arabidopsis D-type cyclin gene expression. Mol Cell Biol. 2000; 20(13): 4513-21.

15. Rolland F, Moore B, Sheen J. Sugar sensing and signaling in plants. Plant Cell. 2002; 14: 185-205.

16. Sherban AS, Salina EA. Epigenetic regulation of expression of vernalization genes. Cytology. 2013; 55(4): 234-7. Russian.

17. Song J, Angel A, Howard M, Dean C. Vernalization - a cold-induced epigenetic switch. J Cell Sci. 2012: 125(16): 3723-31.

18. Stelmach AF, Fayt VI, Martynyuk VR. Genetic systems of the type and rate of development of soft wheat. Cytology and genetics. 2000; 34(2): 39-45. [in Russian]

19. Trevaskis B. The central role of the VERNALIZATION1 gene in the vernalization response of cereals. Functional Plant Biol. 2010; 37(6): 479-87.

20. Stepanenko IL, Smirnova OG, Titov II. A gene regulatory network model for vernalization and seasonal flowering response in winter wheat and barley. Vavilov journal of genetics and breeding. 2012; 12(1): 99-106. Russian.
Olga O. Avksentiieva, Victoriia V. Shulik, Nataliya Yu. Taran

\section{VERNALIZACIJOS KONTRASTINGOMIS TROFINĖMIS SĄLYGOMIS POVEIKIO VRN GENŲ ALELINEI BŪSENAI IR TRITICUM AESTIVUM L. AUGIMO TEMPUI TYRIMAS}

\section{Santrauka}

Ištirtas kontrastingų trofinių sąlygų poveikis vernalizacijos VRN genų alelinei būsenai ir žieminių kviečių veislių Mironovskaja 808 ir Olvia augimo tempui. Vernalizacija buvo atlikta per 45 dienas $4 \pm 1^{\circ} \mathrm{C}$ temperatūroje skirtingomis trofinio palaikymo sąlygomis. VRN genų alelinè būsena identifikuota PGR metodu naudojant specifinius molekulinius žymenis skirtingose vernalizacijos fazèse - 15, 30 ir 45 dienų. Gautų rezultatų duomenimis, visų abiejų žieminių kviečių veislių variantų vrn-a1, vrn-v1 ir vrn-d1 genų recesyvinè būsena 15 -ą ir 30-ą vernalizacijos dieną nepakito. Po 45-osios vernalizacijos dienos Vrn-B1 lokusuose buvo aptikti recesyviniai ir dominantiniai aleliai.

Raktažodžiai: Triticum aestivum L., vernalizacija, VRN genai, trofinis palaikymas, PGR, augimo tempas, VRN genų alelinè būsena 